\title{
Carcinogenic Brominated Hydrocarbon
}

National Cancer Institute

\section{Source}

National Cancer Institute. Carcinogenic Brominated Hydrocarbon. NCI Thesaurus. Code C45388.

A hydrocarbon compound consisting of carbons with one or more bromide atom incorporated in its structure that can increase the risk of human cancer. $(\mathrm{NCl05})$ 